DOI 10.37882/2223-2982.2021.01-2.13

\title{
СЕМАНТИЧЕСКОЕ ПРОСТРАНСТВО ОБРАЗА ЖЕНЩИНЫ В ЯЗЫКОВОЙ КАРТИНЕ МИРА: СОПОСТАВИТЕЛЬНЫЙ АСПЕКТ (НА МАТЕРИАЛЕ ФРАЗЕОЛОГИЗМОВ КИТАЙСКОГО И РУССКОГО ЯЗЫКОВ)
}

\section{THE SEMANTIC SPACE OF A WOMAN'S IMAGE IN LINGUISTIC PICTURE OF THE WORLD: OMPARATIVE ASPECT (BASED ON RUSSIAN AND CHINESE PHRASEOLOGY)}

\section{A. Proskurina M. Khrenovskaya}

Summary: This article covers the modeling of the semantic space of the image of a woman on the basis of Russian and Chinese phraseology. The object of study is a woman's image in Chinese and Russian linguistic picture of the world. The subject of study is the features of the semantic space of a woman's image, which plays an important role in the culture of both ethnic groups. The author provides a classification of the collected idioms, describes the results of the analysis of Chinese and Russian idioms.

Keywords: woman's image, linguistic picture of the world, phraseology, semantic space, Russian, Chinese.

\author{
Проскурина Анастасия Викторовна \\ к.филол.н., дочент, Кемеровский \\ государственный университет \\ proscurina@yandex.ru \\ Хреновская Мария Сергеевна \\ Кемеровский государственный университет \\ mkhrenovskaya@gmail.com
}

Аннотация: Статья посвящена моделированию семантического пространства образа женщины на материале фразеологии китайского и русского языков. Объектом исследования является образ женщины в языковой картине мира китайского и русского народа. Предметом исследования выступают особенности семантического пространства образа женщины, которому принадлежит ведущая роль в культуре обоих этносов. Авторами приводится классификация собранных фразеологических единиц, описываются результаты анализа китайских и русских фразеологизмов. Определяются перспективы исследования.

Ключевые слова: образ женщины, языковая картина мира, семантическое пространство, фразеология, русский язык, китайский язык.

ствительно ли женщина является помощником мужчи ны или все-таки муж - голова, жена - шея; куда захочет, туда и повернет?

Фразеология уже достаточно продолжительное время привлекает внимание исследователей. Особенно усилился интерес к фразеологизмам в последнее десятилетие. Это связано с развитием идей лингвокультурологии - направления лингвистики, которое изучает проявление культуры народа, закрепившееся в языке с помощью его единиц. К числу культуроносных единиц относятся фразеологизмы, которые «прямо или опосредованно (через соотнесенность ассоциативно-образного основания с эталонами, символами, стереотипами национальной культуры) несут в себе культурную информацию о мире и социуме» [4, с. 45]. Так, В.Н. Телия отмечает: «Для полноты описания культурной значимости фразеологизмов необходимо выявить в их значении все имплицитные культурные смыслы, являющиеся тем звеном, которое служит посредником между языком и культурой, о чём свидетельствует та культурная окраска, которую привносят фразеологизмы в дискурсы разных типов» $[9$, с. 9]. 
Статья раскрывает образ женщины, который закрепился в языковой картине мира и стал частью семантического пространства носителей русского и китайского языков. Семантическое своеобразие и уникальность фразеологизмов определяют их роль в создании образа женщины в языке и раскрывают жизненный уклад и особенности мировидения носителей русского или китайского языков.

Материалом для исследования послужили китайские и русские фразеологические единицы (101), семантика которых участвует в формировании образа женщины и позволяет выявить отношение носителей языка к женщинам. Материал был получен путем сплошной выборки из китайско-русских словарей $[2 ; 3]$, фразеологических словарей русского языка $[1 ; 5 ; 6]$.

Выбор обозначенного материала обусловлен тем, что, во-первых, образ женщины оказывается универсальным, определяет своеобразие каждой культуры; во-вторых, наряду с общими ситуациями женщинам свойственны национально обусловленные ситуации, которые высвечивают особенности мировидения представителей разных этносов. Выявление ракурсов восприятия женщин со стороны носителей обозначенных языков представляет собой один из важнейших аспектов изучения языковой картины мира.

Семантико-структурный анализ собранных нами китайских фразеологизмов позволил разделить их на три группы, во главе каждой из которых стоит определенный признак, который объединяет единицы внутри. Были обнаружены следующие параметры: внешность, наличие или отсутствие замужества и качества характера.

В структуре китайских фразеологизмов первой группы мы обнаружили семантический компонент «红》 (Hóng), обозначающий красный цвет и являющийся признаком привлекательности, живости, счастья; например «红裙》 (Hóngqún) - красная юбка или «红粉》 (Hóngfěn) румяна да белила - оба варианта переводятся как «красивая девушка». Еще одной составляющей фразеологизмов, описывающих прекрасных женщин, является «玉» (уй) - яшма, полудрагоценный камень. Фразеологические единицы, содержащие в себе данный иероглиф, подчеркивают ценность и уникальность красивых женщин.

Однако тех, кто не соответствует стандартам красоты, называют, например, «容貌丑陃之女》 (Róngmàochǒulòuzhinnü), где «貌丑》 (màochǒu) значит безобразный, отвратительный, а «丑陃》 (chǒulòu) уродливый, непривлекательный, гадкий, ужасный: экспрессия в данном фразеологизме достигается с помощью использования двух конструкций, которые показывают абсолютную непривлекательность определенной женщины.
Во фразеологических единицах второй группы особое внимание уделено женщинам, не имеющим мужа: « 老姑娘》 (Lǎogūniáng) и «老处女» (lăochǔnü). Оба они переводятся как «старая дева». Их можно считать синонимами, поскольку отличие есть лишь в иероглифах, обозначающих женщину: «姑娘» (gūniáng) u «处女» (chǔnü), a 《老》 (lăo) значит старый. Остаться без мужа - «嫁不出去》 (jiàbùchūqù) - не успеть или не суметь выйти замуж.

Фразеологизмы последней группы содержат в себе иероглифы, обозначающие мифические существа или представителей потустороннего мира. Злых женщин в Китае называют «泰妇》 (Tàifù) или 《罗刹女》 (luóchànü) - женщина-вампир, где «罗刹》 (luóchà) из санскрита ракшас - это демон, пожирающий людей и несущий разрушения. В то время как истеричных женщин характеризуют как 《患癔病的女人» (Huànyibìngdenürén) - страдающая истерией. Здесь «患» (huàn) употребляется в значении страдать.

Проведя анализ собранных нами фразеологических единиц, мы обнаружили, что замужество для китайской женщины является единственным вариантом того, как можно прожить жизнь; иначе ее будут сопровождать одиночество и несчастье. Красивая женщина является святой, яркой, манящей, она счастлива сама и принесет счастье другим, а непривлекательная воспринимается в несколько раз хуже, чем она на самом деле есть, ее образ утрируется в глазах окружающих, она становится слишком некрасивой. Женщина, обладающая склочным характером, - к несчастью - она представляет собой демона, который поедает души людей. Таким образом, женщина в Китае должна быть красивой, иметь мужа и быть покладистой и послушной, иначе она обречена на одиночество, потому что, будучи непокорной и злой, она отдаляет людей от себя.

В результате семантико-структурного анализа фразеологизмы русского языка были разделены на семь групп на основе следующих параметров: возраст, социальная роль (мать), наличие или отсутствие брака или партнёра, внешние характеристики. Также важными критериями являются умственные способности женщины, род ее занятий в жизни, ситуации измен. Каждый из фразеологизмов выявляет отношение российского общества к женщине, её роль, предназначение.

Фразеологизмы первой группы характеризуют женщин в зависимости от возраста. Пожилым дамам даются названия чертова перечница или старая вешалка. Прилагательные в обоих фразеологизмах несут негативную оценку, что говорит об оценке двух качеств в совокупности: возраста и характера. Мы можем заметить негативную окраску фразеологических единиц. Однако фактором, влияющим на отрицательный смысл, является характер женщины преклонного возраста: склочный, 
скверный, сложный. К этой характеристике имеет причастность наименование черт, упомянутое в первом фразеологизме, так или иначе олицетворяющий зло. О молодой женщине можно сказать во ивете лет, о женщине среднего возраста - бальзаковский возраст. Женщины среднего или бальзаковского возраста названы так по причине выхода романа «Тридцатилетние женщины» Оноре Бальзака. Данный фразеологизм не несёт в себе ни положительного, ни отрицательного смысла.

В составе следующей группы фразеологизмов обнаруживаются единицы, связанные с беременностью и материнством. Само по себе явление беременности принято называть интересным положением. Женщину, родившую ребенка, сравнивают с мученицей - разрешаться от бремени - употребляя существительное со значением тяжелой ноши, однако в то же время возносят ее до уровня творца - произвести на свет - при помощи глагола, который обозначает процесс создания чего-либо. Также беременную женщину называют с бочиной, брюшонко вяжется, крепкая брюхом, с брюхом, тем самым характеризуя женщину как «носителя» ребёнка.

Фразеологизмы третьей группы характеризуют женщину в ситуации брака. Она представляет собой самого близкого мужу человека, поскольку зовется подругой жизни и дражайшей половиной, она будет со своим мужчиной до скончания своих дней. Эти фразеологизмы характеризуют ее как верную, покорную и любящую женщину, она отдает свои руку и сердце одному единственному.

Четвертая группа объединила фразеологизмы, которые транслируют образ женщины, выступающей в роли матери. Он имеет место в бранных выражениях: показать кузькину мать, по матушке, к чертовой матери. В данном случае раскрываются такие черты женщины, как матери: строгость, непреклонность. Здесь мы снова наблюдаем связь с чертом, это значит, что женщина в образе матери может быть свирепой, вспыльчивой, способной к наказанию.

Самой обширной группой фразеологизмов о женщине является группа, где параметром для характеристики является внешность. Привлекательных женщин называют лакомым кусочком, картинкой, красной девичей: они радуют глаз, заставляют любоваться ими, они приятны и на вкус, и на взгляд, их красота кричит и хочет, чтобы о ней знали, красный цвет в значении «красивый» говорит о женщине как об уверенной, яркой и страстной. Описание нагой женщины как в костюме Евы говорит нам о том, что женщина святая, однако в ней есть и доля грешности. Женщины с изъянами же воспринимаются утрировано - бог посмотрел на её ноги и изобрёл колесо (о женщине с кривыми ногами), страшнее атомной войны (о некрасивой женщине), а также они теряют свое женское начало - синий чулок - когда они не являются привлекательными или обаятельными. Данные фразеологизмы показывают важность красоты как черты образа женщины: если женщина некрасива, значит, это не женщина, она из прекрасной, обольстительной и яркой особы превращается в ничто.

Следующая группа вобрала в себя фразеологизмы с описанием характера. Женщины обозначаются такими фразеологическими единицами, как светская львица строптивная, «опасная» женщина. Сравнение с женской особью льва указывает на такие черты, как гордость, страсть, однако в то же время холод и рассудительность. Сильные, волевые женщины могут держать под каблуком мужчин, а они, в свою очередь, держатся за бабью юбку, т. е. женщина смотрит на таких свысока, показывая свой характер. «Базарными торговками называют тех», кто делает что-либо неподобающим образом - крикливые, наглые, беспардонные и скандальные женщины, обладающие склочным характером. Не велика боярыня - данный фразеологизм применяется к женщинам, думающим о себе как о представительнице привилегированных слоёв общества, которым следовало бы поступиться некоторыми своими привычками. К избалованным женщинам, которым многое позволяют и спускают с рук, применятся такой фразеологизм, как маменькина дочка. Им присущи инфантильность, ветреность и наивность, возможно, глупость. Валять, строить, ломать дурочку могут женщины, обладающие такими чертами характера, как инфантильность, игривость, также глупость, однако за ребячеством может скрываться ум и расчетливость.

Образ женщины также формируется через фразеологизмы, выражающие эмоциональное состояние, отношение. Женщинам может приписываться такое качество, как склонность к обману, мечтательности: «бабьими сказками» называют выдумки и небылицы. В выражении «мать честная», которое является восклицанием, несущим в себе значение избытка каких-либо чувств, прилагательное «честная» означает уважаемая, почтенная. Это говорит о том, что образ матери для русского человека является святым, непоколебимым и занимающим особое место в жизни.

Исходя из того, состоит ли женщина в браке или нет, ее образ отражен в следующих фразеологизмах. Немолодую женщину, не состоявшую в браке, называют старой девой или христовой невестой, это значит, что она, будучи никому ненужной, неинтересной, непривлекательной, проведет остаток своих дней в одиночестве. Само же явление невыхода замуж обозначается такими фразеологическими единицами, как в девках сидеть и остаться вековушею. Данные фразеологизмы подчеркивают основное предназначение женщины, по мнению русского народа, выйти замуж, стать матерью, хранительницей домашнего очага. 
Умственные способности женщины, как и красота, сильно утрированы во фразеологии, если женщина глупа или необразованна. Бомба замедленного действия так говорят о женщине за рулем автомобиля, к которой складывается отношение, будто она вот-вот взорвётся, принесет беду, несчастье и разрушения. Глупую женщину называют бутылкой порозной - пустой, с воздухом в голове вместо ума. Фразеологическую единицу Алиса в стране чудес применяют по отношению к глупой женщине, которой больше присущи наивность, ребячество и ветер в голове, нежели необразованность.

Ещё одна группа фразеологизмов сформировалась в связи с непристойным образом жизни женщины. Распутные женщины называются вавилонскими блудницами, которые ходят по рукам, треплют юбки или хвосты и наставляют рога. В данных фразеологизмах женщина утрачивает свою ценность, поскольку становится не человеком, а чем-то бездушным, предметом обихода, который может быть использован не одним человеком, как перчатки.

Проанализировав фразеологизмы русского языка, мы можем сделать вывод о том, что образ женщины в языке русского народа предстает многоаспектным, семантически емким и разноплановым. Женщина являет собой покорную, кроткую хранительницу очага, которая, однако, может обладать волевым характером и силой. Истинной женщиной является красивая, молодая замужняя девушка, обладающая мудростью. Однако все те, кто не соответствует стандартам красоты, чей характер не подобает истинной женщине, практически теряют свой образ. Порицается также и распутный образ жизни, который также отдаляет женщин от идеала. Их обезличивают, опуская до уровня предмета, не имеющего формы, пользы и т.п. Социально неодобряемыми оказываются такие черты характера, как сварливость, склочность, непокорность и инфантильность. Наличие изъянов во внешности гиперболизируется, что говорит о высоком уровне требовательности к женщинам. Однако мать, как одно из проявлений образа женщины, является недосягаемой и святой. Она объединяет в себе образ творца и мученика одновременно, что возносит ее к лику святых. Матери дана безграничная сила, она строга, сурова, но справедлива.

Из вышеизложенного можно заключить, что образ женщины занимает важное место в языковой картине мира китайцев и русских, в сознании которых обнаруживается совокупность универсальных и национально обусловленных аспектов ее восприятия. Отношение к женщине определяет культуру поведения и мышления носителей китайского и русского языков в повседневной жизни, включенность ее в культурно значимый набор ситуаций. Перспективы исследования связаны с расширением анализируемого материала и описанием пропозиционально-фреймовой организации семантического пространства образа женщины в китайской и русской лингвокультурах.

\section{ЛИТЕРАТУРА}

1. Большой фразеологический словарь русского языка / авт.-сост. В.Н. Телия, М.Л. Ковшова. - Москва: АСТ-Пресс, 2010. - 784 с.

2. 大Большой китайско-русский словарь онлайн. Режим доступа: https://bkrs.info/ (дата обращения: 11.12.2019).

3. Готлиб М.0., Хуаин Му Китайско-русский фразеологический словарь / 0.М. Готлиб, МуХуаин. 2-е изд., стереотип. - Иркутск: ИГУ, 2019. - 596 с.

4. Маслова В.А. Лингвокульторология / В.А. Маслова. - М.: Академия, 2001. - 208 с.

5. Мокиенко В.М. Большой словарь русских пословиц / В.М. Мокиенко, Т.Г. Никитина, Е.К. Николаева. - Москва: ОЛМА Медиа Групп, 2010. - 1026 с.

6. Молотков А.И. Фразеологический словарь русского языка / А.И. Молотков. - Москва: Советская энциклопедия, 1968. - 543 с.

7. Попова З.Д. Семантико-когнитивный анализ языка: монография / З.Д. Попова, И.А. Стернин. - Вороне ж: Истоки, 2007. - 250 с.

8. Попова З.Д. Язык и национальное сознание / З.Д. Попова, И.А. Стернин. 3-е изд., перераб. и доп. - Воронеж: Истоки, 2007. - 61 с.

9. Телия В.Н. Фразеология в контексте культуры / В.Н. Телия. - Москва: Языки русской культуры, 1999. - 337 с.

( ) Проскурина Анастасия Викторовна (proscurina@yandex.ru), Хреновская Мария Сергеевна (mkhrenovskaya@gmail.com). Журнал «Современная наука: актуальные проблемы теории и практики» 